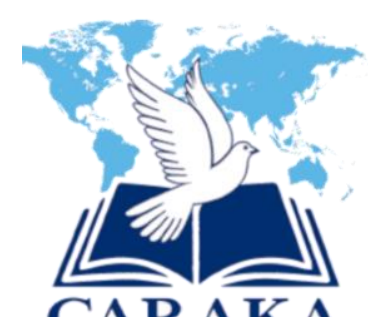
CARAKA

Vol 2, No 1 (Mei 2021)

Https://ojs.sttibc.ac.id/index.php/ibc

Doi: $10.46348 /$ car.v2i1.40

\begin{tabular}{|l|l|l|}
\hline Diserahkan: 4 November 2020 & Diterima: 29 Januari 2021 & Diterbitkan: 11 Maret 2021 \\
\hline
\end{tabular}

\title{
Sikap Hidup Hamba Tuhan Berdasarkan 2 Timotius 2:1-13
}

\author{
Iva Trifena Mayrina Wokas \\ Sekolah Tinggi Teologi Injil Bhakti Caraka Batam \\ Iva.wokas@sttibc.ac.id
}

\begin{abstract}
Attitude to life is fundamental in the life of God's servant. This attitude to life helps servants of God in maintaining the purity of their vocation and avoiding the temptations that exist. Paul wrote 2 Timothy 2: 1-13 as an advice to Timothy to keep his vocation pure and not be influenced by heresy that existed at that time. This research aims to find out the attitude of life in the text of 2 Timothy 2: 1-13 and to find out its implications for God's servants today. This research is a qualitative research with a grammatical historical approach. The attitude of life from the text of 2 Timothy 2: 1-13 is strong in grace, trustworthy, heeding the Word of God, following Jesus' example in enduring suffering and being patient in enduring suffering. By maintaining the attitude of life, a servant of God can be an example for others and also case reports to God's servants can be minimal.
\end{abstract}

Keywords: Attitude of life; God Servant; 2 Timothy 2:1-13

\begin{abstract}
Abstrak
Sikap hidup merupakan hal yang mendasar dalam kehidupan hamba Tuhan. Sikap hidup menolong hamba Tuhan dalam menjaga kemurnian panggilannya dan menghindarkan diri dari godaan yang ada. Paulus menuliskan surat 2 Timotius 2:1-13 sebagai nasihat kepada Timotius untuk menjaga kemurnian panggilannya dan tidak terpengaruh dengan ajaran sesat yang ada pada waktu itu. Penelitian ini bertujuan untuk menemukan sikap hidup dalam teks 2 Timotius 2:1-13 dan mencari implikasinya bagi hamba Tuhan pada masa kini. Penelitian ini merupakan penelitian kualitatif dengan pendekatan historikal gramatikal. Adapun sikap hidup dari teks 2 Timotius 2:1-13 adalah kuat dalam kasih karunia, dapat dipercaya, memperhatikan Firman Tuhan, mengikuti teladan Yesus dalam menanggung penderitaan dan sabar dalam menanggung penderitaan. Dengan menjaga sikap hidupnya seorang hamba Tuhan dapat menjadi teladan bagi orang lain dan juga berita kasus pada hamba Tuhan dapat minim terjadi.
\end{abstract}

Kata Kunci: Sikap hidup; Hamba Tuhan; 2 Timotius 2:1-13 


\section{PENDAHULUAN}

Keberhasilan pelayan Tuhan dalam pelayanan dipengaruhi oleh beberapa faktor pendukung yang salah satunya adalah sikap hidup. Selain keterampilan dan bakat, sikap hidup bagi seorang pelayan Tuhan dapat berfungsi sebagai pendorong untuk dapat berkontribusi dengan maksimal. Dominggus menuliskan bahwa keteladanan hidup merupakan cara yang paling efektif dalam pelayanan. ${ }^{1}$ Hal ini dikarenakan sikap hidup berbicara lebih banyak daripada kata-kata.

Seorang pelayan Tuhan atau yang biasa juga disebut dengan istilah "hamba Tuhan," adalah seorang yang menerima pelayanannya karena kemurahan Allah (2 Korintus 4:1). Karena itu ia sewajarnya tidak menyebabkan orang lain tersandung, supaya pelayanannya jangan sampai dicela (2 Korintus 6:3). Rasul Paulus menyebutkan bahwa dalam segala hal ia menunjukkan bahwa dirinya adalah pelayan Allah. Antara lain dalam hal menahan dengan penuh kesabaran dalam penderitaan, kesesakan dan kesukaran, dalam menanggung dera, penjara dan kerusuhan, dalam berjerih payah, dalam berjaga-jaga dan berpuasa; dalam kemurnian hati, pengetahuan, pengetahuan, kesabaran, dan kemurahan hati, dalam Roh Kudus dan kasih yang tidak munafik serta dalam pemberitaan kebenaran dan kekuasaan Allah (2 Korintus 6:4-7a). Namun fenomena di lapangan seringkali menunjukkan perilaku hamba Tuhan yang tercela. Salah satu contohnya adalah kasus yang terjadi di Surabaya namun barubaru saja terangkat ke media. ${ }^{2}$

Paulus memberikan nasihat-nasihat untuk memperlengkapinya dalam pelayanan. Di dalam Alkitab, teks 2 Timotius 2:1-13 menyinggung tentang sikap hidup hamba Tuhan. Di dalam teks ini Paulus menuliskan bahwa hamba Tuhan dinyatakan sebagai pelayan dari Tuhan Allah yang dipanggil untuk menunaikan tugas pemberitaan Injil. Swindoll mengatakan bahwa seorang hamba Tuhan adalah seorang yang memiliki karakter seperti Yesus, yang mana ia memiliki sikap miskin di hadapan Allah, lemah lembut, lapar dan haus akan kebenaran, murah hatinya, suci hatinya, pembawa damai dan rela dianiaya oleh sebab kebenaran. ${ }^{3}$ Sementara itu, Andrew Murray mengatakan:

Seorang hamba adalah orang yang selalu bekerja sesuai apa yang tuannya kehendaki dan hanya mencari apa yang menyenangkan dan menguntungkan bagi tuannya (Markus 10:45). Ia tidak merasa malu bekerja sebagai bawahan karena ia menyadari bahwa melayani orang lain juga adalah tugasnya. ${ }^{4}$

\footnotetext{
${ }^{1}$ Sara L Sapan and Dicky Dominggus, "Tanggung Jawab Penggembalaan Berdasarkan Perspektif 1 Petrus 5:1-4,” Jurnal Teologi Amreta 3, no. 2 (2020): 124-145.

2 Erwin Johanes, "16 Tahun Cabuli Jemaat, Pendeta Diringkus Saat Hendak Ke Luar Negeri,” Harian Aceh.Co.Id, last modified 2020, accessed March 7, 2020, http://www.harianaceh.co.id/2020/03/07/mau-kabur-keluar-negeri-pendeta-hanny-layantara-yang-cabuli-jemaat-ditangkap/.

${ }^{3}$ Charles R Swindoll, Improving Your Serve: The Art of Unselfish Living (Texas: The World Inc, 1981), 123.

${ }^{4}$ Andrew Murray, Like Christ (Pennsylvania: Whitaker House, 1983), 25.
} 
Dari beberapa pendapat di atas, diambil kesimpulan bahwa hamba Tuhan adalah seorang hamba yang memiliki karakter seperti Yesus, rela dan tidak malu untuk bekerja sesuai kehendak Tuhan, memberitakan Injil dan melayani sesamanya demi menyenangkan Tuhan.

\section{METODE PENELITIAN}

Penelitian ini merupakan penelitian kualitatif dengan menggunakan pendekatan historikal gramatika. Historikal Gramatikal merupakan metode yang digunakan untuk menemukan makna mula-mula dari suatu teks dan dilakukan dengan eksegesis teks. ${ }^{5}$ Metode historikal gramatikal dalam penelitian ini digunakan dalam menemukan makna mula-mula dari teks 2 Timotius 2:1-13.

\section{HASIL DAN PEMBAHASAN}

\section{Latar Belakang Surat 2 Timotius}

Surat 1 dan 2 Timotius ini tergolong sebagai surat-surat penggembalaan atau pastoral. ${ }^{6}$ Disebut demikian karena "hanya surat $1 \& 2$ Timotius dan Titus itulah yang ditujukan kepada individu-individu dalam kepemimpinan gereja, dan kebanyakan berpusat kepada kehidupan dan kegiatan pribadi pemimpin-pemimpin tersebut." " Isi surat 2 Timotius ini terkesan lebih personal oleh karena Paulus banyak menasihati Timotius berkaitan dengan tugas pelayanannya, seperti seorang ayah yang menasihati anaknya. "Surat yang memakai namanya ini dimaksudkan untuk membesarkan hati dan meneguhkan dia untuk menerima tugas berat yang dilimpahkan Paulus kepadanya." 8 Sedikit berbeda dengan surat pertama yang isinya lebih banyak mengenai kehidupan jemaat.

Dalam surat kedua ini Paulus menasihati Timotius supaya bertekun dalam pelayanan (1:3-18), ia mengajak Timotius untuk ikut menderita demi Injil (2:1-13), ia juga mendorong Timotius untuk memenuhi panggilan pelayanannya sebagaimana Paulus sendiri telah sampai di garis akhir pelayanan dan sudah mendekat kematian (4:1-8). Marthen Mau menuliskan bahwa Paulus menuliskan surat 2 Timotius supaya Timotius dapat menjaga kemurnian hidupnya agar tetap berpadanan dengan Injil dan tidak terkontaminasi dengan ajaran sesat. ${ }^{9}$ Sementara itu A. Duane Litfin mengatakan, "The primary theme of the letter is the need for

\footnotetext{
${ }^{5}$ Walter A Elwell, Baker's Evangelical Dictionary of Biblical Theology (Grand Rapids Michigan: Carlisle, Cumbria, Bakker Pub, 1996).

${ }^{6}$ Merrill C Tenney, Survey Perjanjian Baru (Malang: Gandum Mas, 2001), 412.

${ }^{7}$ Philip Jhonston, IVP Introduction to the Bible (Bandung: Yayasan Kalam Hidup, 2011), 129.

${ }^{8}$ Tenney, Survey Perjanjian Baru, 415.

${ }^{9}$ Marthen Mau, "Panggilan Timotius Menurut 2 Timotius 2:2 Dan Implikasinya Bagi Kompetensi Guru Pendidikan Agama Kristen," CARAKA: Jurnal Teologi Biblika dan Praktika 1, no. 2 (2020): 181.
} 
faithfulness in the face of hardship." ${ }^{10}$ Liftin memandang bahwa surat 2 Timotius ini berisi penekanan Paulus akan pentingnya kesetiaan di dalam menghadapi penderitaan.

\section{Sikap Hidup Seorang Hamba Tuhan Berdasarkan 2 Timotius 2:1-13}

\section{Kuat Dalam Kasih Karunia}

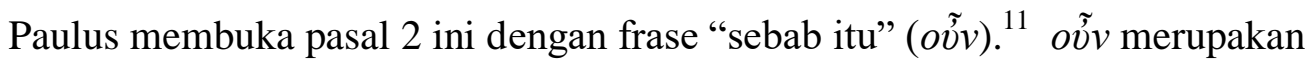
konjungsi yang menegaskan bahwa bagian selanjutnya merupakan kelanjutan dari bagian yang sebelumnya. ${ }^{12}$ Dengan demikian dapat disimpulkan bahwa ayat 1 ini masih berhubungan dengan ayat-ayat sebelumnya yang merupakan bagian dari pasal 1.

Nasehat pertama untuk Timotius pada bagian ini adalah "jadilah kuat." Frase "jadilah

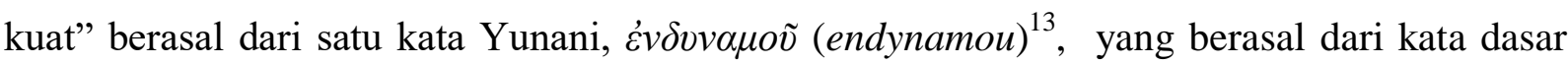

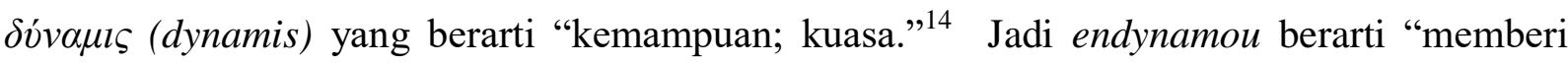
kuasa; menjadikan kuat; atau menguatkan."15 Bentuk kata ini adalah kata kerja Present imperative passive yang berarti kata kerja ini dikenakan kepada subjek dan merupakan sebuah perintah yang harus terus dilakukan oleh subjek yang dimaksud. ${ }^{16}$ Artinya, Paulus menginginkan agar Timotius dikuatkan terus menerus.

Pada pasal 1 Paulus telah mengingatkan kepada Timotius bahwa ia telah beroleh karunia dari Allah yang harus terus ia kobarkan (1:6). Bagi Paulus, Allah memberikan bukan roh ketakutan, melainkan roh yang membangkitkan kekuatan, kasih dan ketertiban (1:7). Kata "kekuatan" pada pasal 1 ayat 7 ini adalah $\delta v v \alpha ́ \mu \varepsilon \omega \varsigma$ (dynameōs) yang berasal dari kata dasar

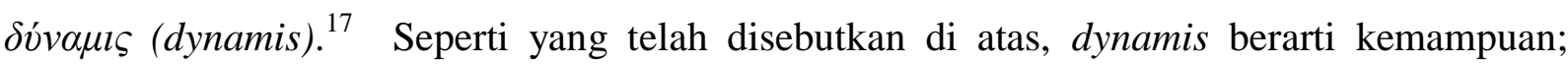
kuasa. Namun kemampuan dan kuasa yang terkandung dalam kata dynamis ini bukanlah kemampuan dan kuasa yang berasal dari diri manusia. Tetapi hal ini merupakan kemampuan dan kuasa Allah (ilahi) yang bekerja dalam keberadaan manusia yang lemah dan rusak ini. ${ }^{18}$ Akar kata yang sama juga muncul dalam Kis.1:8, "kamu akan menerima kuasa jika Roh

\footnotetext{
${ }^{10}$ John F Walvoord and Roy B. Zuck, The Bible Knowledge Commentary: An Exposition Of The Scriptures New Testament (Illinois: Victor Books, 1983), 749.

${ }^{11}$ Jay P Green, The Interlinear Biblie:Hebrew-Greek-English (Indiana: Sovereign Grace Publisher, 1986).

12 James Strong, The New Strong's Exhaustive Concordance of The Bible (Nashvile: Thomas Nelson, 1990).

${ }^{13}$ Green, The Interlinear Biblie:Hebrew-Greek-English.

${ }^{14}$ Gerhard Kittel, Gerhard Friedrich, and Geoffrey W Bromiley, Theological Dictionary of the New Testament: Abridged In One Volume (Grand Rapids Michigan: Williams B. Eerdmans Publshing Company, $1985), 186$.

${ }^{15}$ Ibid.

${ }^{16}$ Cleon L Rogers Jr and Cleon L Rogers III, The New Linguistic and Exegetical Key To The Greek New Testament (Grand Rapids Michigan: Zondervan Publishing, 1998).

${ }_{17}^{17}$ Green, The Interlinear Biblie:Hebrew-Greek-English.

${ }^{18}$ Kittel, Friedrich, and Bromiley, Theological Dictionary of the New Testament: Abridged In One Volume.
} 
Kudus turun ke atasmu dan kamu akan menjadi saksiku di Yerusalem...sampai ke ujung dunia." ${ }^{19}$ Demikianlah dahsyatnya kuasa Allah yang bekerja di dalam pribadi manusia yang menerima Roh-Nya.

Paulus juga melihat Yesus telah menyelamatkan dan memanggil Paulus dan Timotius (1:9). Paulus menegaskan bahwa karya Yesus ini bukan berdasarkan perbuatan dirinya dan Timotius, tetapi oleh karena maksud dan kasih karunia Allah semata. Kasih Karunia Allah ini telah nyata di dalam diri Yesus Kristus yang telah mematahkan kuasa maut dan mendatangkan hidup yang kekal (1:10). Kata "kuasa" dalam ayat 10 ini bukanlah dynamis, tetapi $\theta \dot{\alpha} v \alpha \tau o v$ (thanaton) yang bermakna "kematian." Yesus Kristus adalah lebih besar dari kuasa apapun di dunia ini, bahkan kematian sekalipun. Dan kuasa (dynamis) sebesar inilah yang telah Allah berikan kepada Paulus dan Timotius. Itulah sebabnya Paulus dengan yakin mengatakan bahwa ia rela menderita dalam pemberitaan Injil oleh karena ia tahu kepada siapa ia percaya dan Paulus yakin bahwa Allah berkuasa memelihara apa yang telah Ia percayakan kepadanya hingga hari Tuhan (1:12).

Melalui surat ini Paulus hendak menyadarkan Timotius bahwa sekalipun ia memiliki kelemahan-kelemahan, tetapi ia telah menerima kuasa dari Allah untuk memberitakan Injil. Karena kasih karunia-Nya juga Ia telah menyelamatkan dan memanggil Timotius. Oleh karena itu, Timotius harus terus menerus menguatkan dirinya untuk dapat terus memberitakan Injil.

\section{Dapat Dipercayai}

Ayat 2 ini erat kaitannya dengan pasal 1:13-14. Di ayat 13 Paulus memerintahkan Timotius untuk memegang ajarannya oleh karena itu adalah contoh ajaran yang sehat. Jadi nasehat kedua bagi Timotius adalah "percayakanlah." Kata Yunani yang dipakai adalah $\pi \alpha \rho \alpha ́ \theta o v$ (parathou). ${ }^{21}$ Bentuknya adalah kata kerja aorist imperative middle, ${ }^{22}$ dan berasal dari kata dasar $\pi \alpha \rho \alpha \tau i \theta \eta \mu l$ (paratithémi). Aorist imperative dipakai untuk menyatakan perintah untuk melakukan sesuatu pada waktu perintah tersebut diberikan. ${ }^{23}$ Sementara voice middle lebih mendekati arti aktif daripada pasif. ${ }^{24}$ Oleh sebab itu Timotius harus melakukannya secara aktif, yaitu terus menerus. Yang menarik adalah bahwa kata paratithémi

\footnotetext{
${ }^{19}$ Green, The Interlinear Biblie:Hebrew-Greek-English.

${ }^{20}$ Ibid.

${ }^{21}$ Ibid.

${ }^{22} \mathrm{Jr}$ and III, The New Linguistic and Exegetical Key To The Greek New Testament.

${ }^{23}$ J W Wenham, Bahasa Yunani Koine (Malang: SAAT, 1987), 79.

${ }^{24}$ Ibid, 72.
} 
telah muncul dalam 2 Timotius 1:14, dalam bentuk $\pi \alpha \rho \alpha \theta \dot{\eta} \kappa \eta v$ (parathēkēn) namun diterjemahkan "harta yang indah, yang telah dipercayakan-Nya."

Dalam pengertian umum, kata paratithémi bermakna "to set beside or before, to present (menyajikan/memberikan). "25 Namun pengertian teknisnya adalah “to deposit, to entrust in the legal sense of leaving an object in another's keeping, with strict penalties for embezzlement." 26 Artinya adalah mempercayakan suatu objek secara legal kepada penjagaan seseorang, dan ada hukuman jika terjadi pencurian atau penggelapan terhadap objek tersebut. Makna ini sejalan dengan anak kalimat berikutnya dalam ayat 2 ini, "percayakanlah itu kepada orang-orang yang dapat dipercayai, yang juga cakap mengajar orang lain.”

Dengan sungguh-sungguh Paulus telah mempercayakan Injil kepada Timotius. Sama halnya dia ditugaskan untuk menyampaikan Injil kepada mereka, yang juga wajib menyampaikannya kepada orang lain. Perhatikan syarat yang dituntut bagi pelayan demikian - 'dapat dipercayai' dan 'kecakapan mengajar. ${ }^{27}$

Jadi perintah untuk mempercayakan ajaran Paulus yang telah Timotius dengar ini, bukanlah perintah biasa. Namun Paulus sangat mengharapkan untuk Timotius meneruskan ajarannya dan mempercayakannya kepada orang yang dapat dipercaya dan memiliki kemampuan untuk mengajar orang lainnya. "This has come to be called "the ministry of multiplication,' and it is God's method for propagating the good news of Jesus Christ." 28

\section{Memperhatikan Firman Tuhan}

Kata "perhatikan" berasal dari kata Yunani vóel (noei). vóєı adalah sebuah kata kerja berbentuk present imperatif aktif. ${ }^{29}$ Maknanya adalah perintah untuk melakukan sesuatu secara terus menerus atau berulang kali. ${ }^{30}$ Kata dasar vó $\varepsilon$ adalah voé $\omega$ (noeó) yang bermakna "to direct one's mind to,",31 atau mengarahkan pikiran seseorang kepada sesuatu hal. Namun kata ini juga mengandung pengertian to grasp (memahami), to recognize (mengenali), to understand (mengerti), to imagine (membayangkan). ${ }^{32}$ Jadi Paulus memberikan perintah agar Timotius terus menerus mengarahkan pikirannya kepada apa yang telah Paulus katakan sebelumnya sampai ia benar-benar memahami hal-hal tersebut.

\footnotetext{
${ }^{25}$ Kittel, Friedrich, and Bromiley, Theological Dictionary of the New Testament: Abridged In One Volume, 1179.

26 Ibid.

${ }^{27}$ Donald Gutrhie, Tafsiran Alkitab Masa Kini Vol. 3 (Jakarta: Yayasan Bina Kasih/OMF, 1995), 705.

${ }^{28}$ Walvoord and Zuck, The Bible Knowledge Commentary: An Exposition Of The Scriptures New Testament.

${ }^{29}$ Green, The Interlinear Biblie:Hebrew-Greek-English.

${ }^{30}$ Wenham, Bahasa Yunani Koine, 56.

${ }^{31}$ Kittel, Friedrich, and Bromiley, Theological Dictionary of the New Testament: Abridged In One Volume, 636

32 Ibid.
}

21 | Copyright $\odot$ 2021, CARAKA, ISSN 2722-1407 (Cetak), 2722-1393 (Online) 
Paulus memberikan jaminan bahwa Tuhan akan memberi pengertian dalam segala sesuatu kepada Timotius. Sebagai seorang hamba dari Tuhan Allah, maka adalah penting untuk seorang hamba Tuhan untuk senantiasa memperhatikan firman-Nya. Firman Tuhan haruslah senantiasa menjadi penuntun jalan kehidupan seorang hamba Tuhan. Daniel Ronda menuliskan Firman Allah akan memberi tuntutan sekaligus kekuatan bagi seorang pemimpin dalam menjalankan tugas dan tanggung jawabnya. ${ }^{33}$

\section{Mengikuti Teladan Yesus Dalam Menanggung Penderitaan}

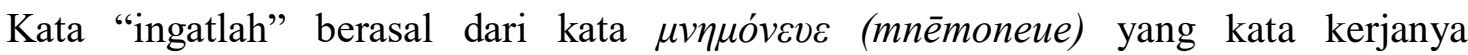
berbentuk present imperatif aktif. ${ }^{34}$ Maknanya adalah to remember (untuk mengingat) dan to mention (menyebutkan atau menyaksikan). ${ }^{35}$ Michel mengatakan bahwa hal "mengingat" yang dimaksudkan, bukan sekedar tindakan mental, namun harus mengobarkan memori yang ada. $^{36}$ Hal ini merupakan perintah Paulus agar Timotius terus menerus mengingat Yesus Kristus, keturunan Daud, yang telah bangkit dari antara orang mati sebagai sumber pemberitaan Injilnya.

Untuk menguatkan Timotius dalam penderitaan, Paulus mengarahkan pikirannya kepada Yesus Kristus yang sudah bangkit. Inkarnasi dan kebangkitan Yesus Kristus, yang dengan sungguh-sungguh diyakini dan dipertimbangkan dengan benar, akan mendukung seorang Kristen yang sedang menanggung segala penderitaan dalam kehidupan sekarang. ${ }^{37}$ Jadi, mengikuti teladan Yesus dalam menanggung penderitaan adalah terus menerus mengingat Yesus Kristus yang sudah bangkit sebagai dasar kekuatan seorang hamba Tuhan dalam pelayanan pemberitaan Injil.

\section{Sabar Dalam Menanggung Penderitaan}

Nasehat ketiga bagi Timotius adalah "ikutlah menderita." Kata Yunani yang dipakai

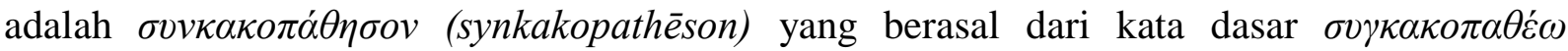
(sugkakopatheó). ${ }^{38}$ Kemudian kata sugkakopatheó berasal dari preposisi $\sigma o ́ v$ dan kata $\kappa \alpha \kappa о \pi \alpha \theta \varepsilon \dot{\varepsilon} \omega$ (kakopatheó). ${ }^{39}$ Preposisi ov́v itu sendiri bermakna "being or acting together

${ }^{33}$ Maria Rukku dan Daniel Ronda, "Pemimpin Yang Memiliki Integritas Menurut 2 Timotius Pasal 2," Jurnal Jaffray 9, no. 1 (2011): 50.

${ }_{34}$ Green, The Interlinear Biblie:Hebrew-Greek-English.

${ }^{35}$ Kittel, Friedrich, and Bromiley, Theological Dictionary of the New Testament: Abridged In One Volume, 596.

${ }^{36}$ Ibid.

${ }^{37}$ Walvoord and Zuck, The Bible Knowledge Commentary: An Exposition Of The Scriptures New Testament.

${ }^{38}$ Green, The Interlinear Biblie:Hebrew-Greek-English.

${ }^{39}$ Ibid. 
carries the sense of supporting or helping one another." ${ }^{, 40}$ Maksudnya adalah turut menanggung sesuatu secara bersama untuk saling mendukung atau menolong. Sementara kakopatheó bermakna "to suffer misfortune, to be in a sorry situation" dan kadang juga dimaknai "to endure evil."41 "In 2 Tim 2:9 Christian suffering is the point ... In 2:3 Timothy is not just sympathize with the apostle in his suffering but to take his share of suffering."42 Jadi Paulus meminta Timotius bukan semata-mata untuk bersimpati atas penderitaan Paulus, tetapi untuk mau juga menanggung penderitaan karena Injil secara terus-menerus, sama seperti yang dilakukan oleh Paulus. Ferdinand Butar-butar menuliskan kata menderita yang digunakan Paulus memberikan signal kepada para gembala, bahwa hidup sebagai pelayan Tuhan harus bersedia tidak masyur, dicemooh dan dilecehkan orang lain. ${ }^{43}$ Bagi butar-butar, menderita dalam pelayanan merupakan kondisi yang harus diterima oleh pelayan Tuhan.

Dalam beberapa versi, ayat ini berbunyi "Join with me in suffering, like a good soldier of Christ Jesus" (NIV). Dalam versi yang lain, "Endure suffering along with me...." (NLT) Sementara dalam terjemahan Bahasa Indonesia Sehari-hari, "Engkau harus turut menderita sebagai prajurit Kristus Yesus yang setia” (BIS) Sebenarnya ajakan Paulus untuk Timotius turut menderita demi Injil, sudah disebutkan di pasal 1:8, “...melainkan ikutlah menderita bagi Injil-Nya oleh kekuatan Allah.” Jadi kata synkakopathēson ini hanya muncul 2 kali di dalam Perjanjian Baru, yaitu di surat 2 Timotius ini. Bauernfeind mengatakan bahwa yang menjadi tema dalam 2 Tim 2:3 ini adalah konsentrasi kepada penyangkalan diri. ${ }^{44}$

Dalam pasal 1 ayat ke-8 Paulus ini menegaskan sekali lagi bahwa Injil yang ia beritakan adalah kebenaran akan, "Yesus Kristus, yang telah bangkit dari antara orang mati, yang telah dilahirkan sebagai keturunan Daud." Namun ia sabar menanggung segala penderitaan itu supaya orang-orang pilihan Allah juga mendapat keselamatan dalam Kristus Yesus dengan kemuliaan yang kekal (2 Tim 2:10). Ajakan Paulus untuk Timotius ikut

menderita dianalogikan seperti sikap prajurit, olahragawan dan petani (ayat 4-6).

Mengenai prajurit, Paulus mengatakan, "Seorang prajurit yang sedang berjuang tidak memusingkan dirinya dengan soal-soal penghidupannya, supaya dengan demikian ia berkenan kepada komandannya." Tidak dapat disangkal bahwa gambaran Paulus mengenai prajurit

\footnotetext{
${ }^{40}$ Kittel, Friedrich, and Bromiley, Theological Dictionary of the New Testament: Abridged In One Volume, 1103.

${ }^{41}$ Ibid, 803.

${ }^{42}$ Ibid.

${ }^{43}$ Ferdinand Butarbutar, "Membangun Pemimpin Hebat Menutur 2 Timotius 2:1-25 Di Gereja Masehi Advent Hari Ketujuh Indonesia," Jurnal Theologia Forum STFT Surya Nusantara 5, no. 1 (2017): 44.

${ }^{44}$ Ibid, 1093.
} 
yang fokus, disiplin dan tunduk pada komandannya ini terinspirasi dari prajurit Roma. ${ }^{45}$ Dalam versi lain, frase "prajurit yang sedang berjuang" diterjemahkan soldier in active service (NAS); man that warreth (KJV); serving as a soldier (NIV); prajurit yang sedang tugas (BIS). Frase ini berasal dari kata kerja $\sigma \tau \rho \alpha \tau \varepsilon v o ́ \mu \varepsilon v o \varsigma$ (strateuomenos). ${ }^{46}$ Maknanya adalah "the individual on military service," 47 yaitu seseorang yang sedang menjalani wajib militer.

Paulus mengatakan bahwa seorang prajurit yang sedang berjuang ini tentunya tidak akan "memusingkan diri dengan soal-soal penghidupan." Dalam terjemahan lain frase ini ditulis, entangled in civilian affairs (NIV); entangled in civilian pursuits (ESV); entangles himself in the affairs of everyday life (NAS); mengusutkan hatinya dengan perkaranya sendiri (TL); tidak akan menyibukkan dirinya dengan urusan-urusannya sendiri (BIS). Frase

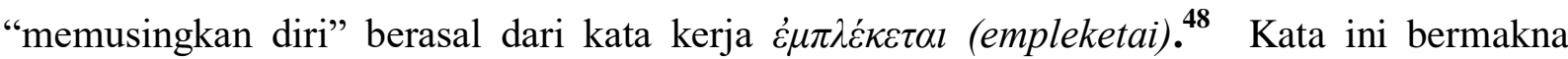
untuk menenun, untuk menjalin, untuk terlibat dengan. ${ }^{49}$

Sementara itu, frase "soal-soal penghidupan" berasal dari 2 kata, yaitu Bíov (biou) dan $\pi \rho \alpha \gamma \mu \alpha \tau$ cials (pragmateiais). ${ }^{50}$ Keduanya adalah kata benda. biou bermakna "manner of life,"51 atau cara hidup. Sementara pragmateiais bermakna "zealous concern about something, business, work, affairs, duties." tentang sesuatu, bisnis, pekerjaan, urusan, tugas. Jadi kalimat "memusingkan diri dengan soalsoal penghidupan" berarti melibatkan diri dengan urusan atau pekerjaan hidup sehari-hari.

Kesimpulannya, seorang prajurit yang sedang dalam peperangan, atau yang sedang melakukan tugasnya, perlu fokus, tidak memusingkan diri dengan hal-hal sehari-hari yang tidak ada hubungannya dengan tugas yang sedang dijalankannya. Tujuan akhirnya adalah untuk menyenangkan komandannya. Paulus memakai analogi prajurit untuk menjelaskan kesiapsediaan terhadap perintah komandan dan patuh dalam menjalankan tugas yang diberikan. ${ }^{53}$ Pada bagian ini Paulus berusaha mengarahkan fokus Timotius kepada tugas pemberitaan Injil yang untuknya ia telah dipanggil, dan supaya Timotius menjalankannya

${ }^{45}$ Walvoord and Zuck, The Bible Knowledge Commentary: An Exposition Of The Scriptures New Testament.

${ }^{46}$ Green, The Interlinear Biblie:Hebrew-Greek-English.

${ }^{47}$ Kittel, Friedrich, and Bromiley, Theological Dictionary of the New Testament: Abridged In One Volume, 1091.

${ }^{48}$ Green, The Interlinear Biblie:Hebrew-Greek-English.

${ }^{49}$ Strong, The New Strong's Exhaustive Concordance of The Bible.

${ }^{50}$ Green, The Interlinear Biblie:Hebrew-Greek-English.

${ }^{51}$ Kittel, Friedrich, and Bromiley, Theological Dictionary of the New Testament: Abridged In One Volume, 290.

52 Ibid, 928.

53 Tenny Sudibyo and Areyne Christi, "Implementasi Prinsip Kepemimpinan Rasul Paulus Berdasarkan Surat 1 Timotius 3:1-13 \& 2 Timotius 2:2-6 Di Kalangan Civitas Akademika Sekolah Tinggi Teologi," Jurnal Excelsior Pendidikan 1, no. 1 (2020): 23-44. 
dengan sungguh-sungguh demi menyenangkan Allah yang telah memanggil dan mengutusnya. "The great care of a soldier should be to please his general; so the great care of a Christian should be to please Christ."

Analogi kedua bagi ajakan Paulus untuk ikut menderita adalah seperti olahragawan, "seorang olahragawan hanya dapat memperoleh mahkota sebagai juara, apabila ia bertanding menurut peraturan-peraturan olahraga" (2:5). Gambaran mengenai seorang olahragawan atau atlit yang sedang berjuang juga bukanlah hal yang baru dalam tulisan Paulus. Gambaran yang sama dituliskannya juga dalam surat 1 Korintus 9:24-27. Metafora ini jelas mengacu pada pertandingan Olimpiade. $^{55}$

Kata "olahragawan" juga diterjemahkan, anyone who competes as an athlete (NIV); an athlete (ESV). Kata Yunani yang dipakai adalah $\dot{\alpha} \theta \lambda \tilde{\eta}$ (athlē), yang berasal dari Kata dasar $\dot{\alpha} \theta \lambda \dot{\varepsilon} \omega$ (athleó). ${ }^{56}$ Dalam ayat ini saja, kata ini muncul 2 kali dalam ayat yang sama. Kali kedua adalah pada kata "bertanding." Secara literal athleó bermakna "to engage in competition or conflict. ${ }^{, 57}$ Dalam 2 Tim. 2:5, kata ini mengandung pengertian pengerahan tenaga, pengorbanan, dan disiplin. ${ }^{58}$

Sementara itu, frase "menurut peraturan-peraturan olahraga" diterjemahkan according to the rules (NIV; ESV; NAS); he strive lawfully (KJV). Kata "peraturan-peraturan" berasal

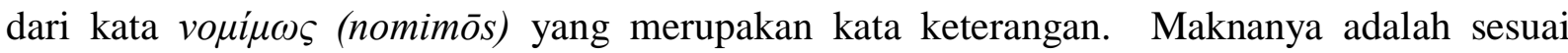
aturan atau perintah. ${ }^{59}$ Walvoord dan Zuck mengatakan,

Every athletic event has its boundaries, its rules; moreover, all who fail to discipline themselves to observe these rules are disqualified. Paul wanted Timothy to run so as to win the crown (cf. 2 Tim 4:7-8) and not be disqualified. This requires a Christian to have strong qualities of discipline, self-control, endurance, and a certain toughness. ${ }^{60}$

Jadi, setiap pertandingan tentunya memiliki batasan dan peraturannya, oleh sebab itu peserta yang gagal mendisiplinkan diri untuk mematuhi aturan-aturan tersebut, pasti didiskualifikasi. Oleh sebab itu Paulus ingin Timotius berlari untuk memenangkan mahkota (band. 2 Tim 4: 7 8) dan tidak didiskualifikasi. Aplikasi hal ini bagi seorang Kristen adalah supaya ia memiliki

\footnotetext{
${ }^{54}$ Henry's Matthew, Matthew Henry Commentary On Whole Bible (Peabody: Hendrickson Publisher, 2002).

${ }^{55}$ Walvoord and Zuck, The Bible Knowledge Commentary: An Exposition Of The Scriptures New Testament.

${ }^{56}$ Green, The Interlinear Biblie:Hebrew-Greek-English. Volume, 625.

${ }^{57}$ Kittel, Friedrich, and Bromiley, Theological Dictionary of the New Testament: Abridged In One

${ }^{58}$ Ibid.

${ }^{59}$ Ibid, 655.

${ }^{60}$ Walvoord and Zuck, The Bible Knowledge Commentary: An Exposition Of The Scriptures New Testament.
} 
kualitas disiplin yang kuat, kontrol diri, daya tahan, dan ketangguhan tertentu. Jadi ketika Paulus mengatakan, "seorang olahragawan hanya dapat memperoleh mahkota sebagai juara, apabila ia bertanding menurut peraturan-peraturan olahraga," maka maksudnya adalah bahwa seorang atlet harus mengerahkan tenaganya, menunjukkan pengorbanan, dan disiplin untuk bertanding sesuai aturan supaya ia pantas menjadi juara.

Analogi terakhir adalah "seorang petani yang bekerja keras haruslah yang pertama menikmati hasil usahanya" (ayat 6). Dalam versi lain, ayat ini berbunyi, The hardworking farmer should be the first to receive a share of the crops (NIV); The husbandman that laboureth must be first partaker of the fruits (KJV); Adapun orang dusun yang berlelah itu, patutlah ia mula-mula mendapat buah-buahan itu (TL); Petani yang sudah bekerja keras, dialah yang pertama-tama berhak mendapat hasil tanaman (BIS). Kata "bekerja keras" berasal

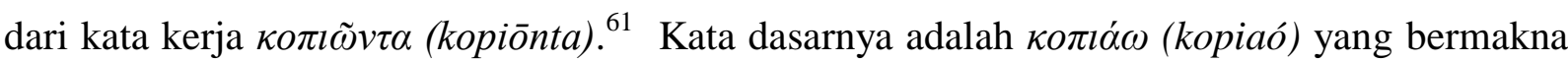
melelahkan diri sendiri, contohnya dari pekerjaan manual yang dilakukannya. ${ }^{62}$ Di bagian lain surat Timotius, yaitu di 1 Timotius 1:4 rasul Paulus memakai kata yang sama ketika ia mengatakan, "Itulah sebabnya kita berjerih payah dan berjuang, karena kita menaruh pengharapan kita kepada Allah yang hidup...."

Sementara itu, frase "menikmati hasil" berasal dari kata kerja $\mu \varepsilon \tau \alpha \lambda \alpha \mu \beta \alpha ́ \alpha \varepsilon \varepsilon \imath v$ (metalambanein). ${ }^{63}$ Kata dasarnya adalah $\lambda \alpha \mu \beta \alpha ́ v \omega$ (lambanó) yang bermakna to take to oneself (mengambil untuk diri sendiri), to receive (menerima), to collect (mengumpulkan), to seize (menyita/ memiliki). ${ }^{64}$ Secara khusus dalam 2 Tim. 2:6, kata ini juga dapat berarti "to take part,"65 atau mengambil bagian. Jadi, Paulus hendak menyampaikan kepada Timotius bahwa hal ia turut menanggung penderitaan, ia harus bersikap seperti prajurit yang fokus dalam perjuangannya dengan cara mengesampingkan urusan hidup sehari-hari. Ia juga harus bersikap seperti seorang atlet yang mengerahkan tenaganya, menunjukkan pengorbanan, dan disiplin untuk bertanding sesuai aturan supaya ia pantas menjadi juara. Sikap terakhir yang Paulus harapkan adalah bahwa Timotius akan berjerih payah seperti petani yang mengolah kebunnya oleh karena ia akan menikmati upah dari kerja kerasnya tersebut. Ketiga ilustrasi ini

\footnotetext{
${ }^{61}$ Green, The Interlinear Biblie:Hebrew-Greek-English.

${ }^{62}$ Kittel, Friedrich, and Bromiley, Theological Dictionary of the New Testament: Abridged In One Volume, 453.

${ }^{63}$ Green, The Interlinear Biblie:Hebrew-Greek-English.

${ }^{64}$ Kittel, Friedrich, and Bromiley, Theological Dictionary of the New Testament: Abridged In One Volume, 495

65 Ibid, 496.
} 
memiliki kesamaan, yaitu menekankan bahwa kesuksesan akan tercapai melalui disiplin, kerja keras dan pikiran yang tertuju kepada satu fokus. ${ }^{66}$

Di ayat 9-10, Paulus menggunakan dirinya sebagai teladan untuk Timotius bertahan dalam penderitaan. Frase "sabar menanggung" berasal dari satu kata kerja Yunani, yaitu $\dot{v} \pi \mu^{\prime} \dot{v} \omega$ (hypomenō). ${ }^{67}$ Secara umum kata ini memiliki pengertian "to stay behind (untuk tetap tinggal), to stay alive (untuk tetap hidup), to expect (untuk berharap), to stand firm (untuk berdiri teguh), to endure (untuk bertahan), to bear (untuk menanggung), to suffer

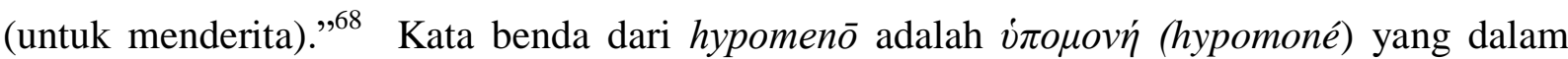
Alkitab bahasa Indonesia sering diterjemahkan "ketekunan atau ketabahan."

Sikap hupomoné tidak dimotivasi dari luar atau dari opini orang, tidak juga dari pengharapan akan mendapat penghargaan, tetapi sikap ketekunan dimotivasi dari dalam, yaitu oleh cinta akan penghormatan. ${ }^{69}$

Paulus membuat sketsa ciri-ciri utama hypomoné sebagai sikap Kristen. Sikap ini tidak berasal dari keberanian atau ketidakpekaan, tetapi dari iman dan harapan (Rm. 8:25). Ini menunjukkan ketekunan dalam masa kekejaman dan ketidakadilan saat ini (Rm. 12: 2; 1 Kor. 3: 7). Secara aktif ini menghasilkan perbuatan baik (Rm. 2: 7), secara pasif ia bertahan di bawah penderitaan (2 Tes. 1: 4; lih. 1 Ptr. 2:20). Orang Kristen tahu bahwa mereka dipanggil untuk menderita (Kisah Para Rasul 14:22), dan mereka menunjukkan iman mereka dengan bertahan dengan cara yang sama (lih. 2 Tim 2: 10). Penderitaan menghasilkan karakter ketahanan, dan daya tahan (Rm. 5: 3-4). Daya tahan ini diberikan oleh Allah (Rm. 15: 5) dan terkait erat dengan iman dan kasih (1 Tim. 6:11; 2 Tim. 3:10). Ia memiliki janji bahwa mereka yang mati bersama Kristus, jika mereka bertahan, juga akan memerintah bersama dia (2 Tim. 2: 11-12). ${ }^{70}$

Jadi sekali lagi Paulus menegaskan bahwa alasan penderitaannya dan pemenjaraannya adalah karena pemberitaan Injil Yesus Kristus. Namun Paulus sabar menanggung semua ini asalkan lebih banyak orang mendengar dan menerima Injil itu sehingga mereka beroleh selamat. Mereka inilah yang disebut sebagai orang-orang pilihan Allah. Hal ini merupakan teladan Paulus dan yang ia kehendaki untuk Timotius juga miliki di dalam ia melakukan pelayanan pemberitaan Injil.

Keyakinan Paulus untuk sabar menanggung segala penderitaannya juga karena ia meyakini bahwa ada penghargaan atas kesetiaannya tersebut. Seperti yang ditunjukkan pada ayat-ayat selanjutnya (11-13),

\footnotetext{
${ }^{66}$ Walvoord and Zuck, The Bible Knowledge Commentary: An Exposition Of The Scriptures New Testament.

${ }^{67}$ Green, The Interlinear Biblie:Hebrew-Greek-English.

${ }^{68}$ Kittel, Friedrich, and Bromiley, Theological Dictionary of the New Testament: Abridged In One Volume, 582

${ }^{69}$ Ibid.

${ }^{70}$ Ibid, 583.
} 
Benarlah perkataan ini: "Jika kita mati dengan Dia, kitapun akan hidup dengan Dia; jika kita bertekun, kitapun akan ikut memerintah dengan Dia; jika kita menyangkal Dia, Diapun akan menyangkal kita; jika kita tidak setia, Dia tetap setia, karena Dia tidak dapat menyangkal diri-Nya."

Bagian ini kemungkinan diambil dari himne yang populer pada masa itu atau serangkaian kata-kata mutiara, yang dimaksudkan untuk mengilhami kesetiaan sampai mati dan harapan untuk berbagi dalam kemuliaan kekal Kristus. ${ }^{71}$ Bagian ini dimulai dengan kalimat, "benarlah perkataan ini...." Kalimat ini merupakan sebuah ciri khas Paulus yang tercantum beberapa kali dalam surat-surat Pastoral. Contohnya dalam 1 Tim 1:15; 3:1; 4:9; dan Titus 3:8.

Perkataan Paulus di Ayat 11-13 ini mengandung dua penafsiran. Pertama adalah bersifat positif yang berisi penghargaan. Bagi yang mati dengan Kristus, penghargaan yang ia dapat adalah akan hidup dengan Dia (ayat 11) . Bagi mereka yang bertekun (hypomenomen) ${ }^{72}$ akan ikut memerintah dengan Dia (ayat 12). Dalam surat Roma Paulus pernah mengatakan hal yang senada,

Dan jika kita adalah anak, maka kita juga adalah ahli waris, maksudnya orang-orang yang berhak menerima janji-janji Allah, yang akan menerimanya bersama-sama dengan Kristus, yaitu jika kita menderita bersama-sama dengan Dia, supaya kita juga dipermuliakan bersama-sama dengan Dia ( $\mathrm{Rm}$ 8:17).

Penafsiran keduakedua adalah bernada negatif yaitu barangsiapa yang menyangkal Kristus, maka Kristus juga akan menyangkalnya. Peringatan ini bukanlah hal yang baru karena Yesus telah terlebih dahulu mengatakannya kepada para murid-Nya, yaitu dalam Injil Lukas 12:9 dan Matius 10:33.

Namun kemudian bagian ini ditutup dengan perkataan bernuansa positif dan menghibur, "jika kita tidak setia, Dia tetap setia, karena Dia tidak dapat menyangkal diri-Nya" (2 Tim. 2:13). Bagian terakhir ini sekali lagi menegaskan akan kasih karunia Allah yang jauh melebihi ketidaksetiaan manusia. Dan kasih karunia Allah inilah yang pertama kali ditegaskan oleh rasul Paulus sejak ayat pertama pada pasal 2 ini, "Sebab itu, hai anakku, jadilah kuat oleh kasih karunia dalam Kristus Yesus."

Dari uraian di atas, yang dimaksud dengan sabar dalam menanggung penderitaan adalah rela berkorban menanggung penderitaan karena Injil secara terus-menerus seperti prajurit, olahragawan dan petani yang berfokus, disiplin, tunduk pada komandan, mengerahkan tenaga, menunjukkan pengorbanan, dan bekerja keras oleh karena ia akan mendapat penghargaan dari Allah yang dilayaninya.

${ }^{71}$ J D Douglas, The New Bible Commentary (London: Intervarsity Press, 1975).

${ }^{72}$ Green, The Interlinear Biblie:Hebrew-Greek-English. 


\section{Implikasi Bagi Hamba Tuhan Pada Masa Kini}

Sebagai pribadi yang menerima pelayanannya karena kemurahan Allah, maka seorang hamba Tuhan harus memiliki sikap-sikap hidup yang sesuai dengan kehendak Allah. Dalam 2 Timotius 2:1-13 rasul Paulus memberikan nasihat mengenai sikap hidup yang harus dimiliki oleh seorang hamba Tuhan. Nasihat-nasihat Paulus ini sangat relevan bagi para hamba Tuhan masa kini. Tantangan jaman, ajaran-ajaran sesat, godaan dunia, dan keinginan-keinginan daging seringkali menjadi alasan yang membuat seorang hamba Tuhan jatuh sehingga hidupnya tidak menjadi berkat bagi banyak orang. Hal ini jelas menodai pemberitaan Injil yang selama ini ia lakukan. Beberapa sikap yang harus dimiliki hamba Tuhan adalah disiplin, kerja keras dan fokus seperti yang ditunjukkan Paulus melalui gambaran seorang prajurit, olahragawan, dan petani. Sikap lain yang perlu dikembangkan dalam pelayanan adalah terus menerus menguatkan diri dalam segala kondisi serta sabar menanggung penderitaan. Sikap ini bukan muncul karena kondisi dari luar melainkan dimotivasi dari dalam diri, yaitu oleh cinta kepada Allah dan hormat akan panggilan-Nya. Dasar mengembangkan sikap-sikap tersebut adalah karena Yesus telah menyelamatkan dan memanggil, karena Roh Allah diberikan bagi hamba-Nya dan karena firman Tuhan diberikan untuk menuntun para hamba-hamba-Nya.

Tujuan akhir daripada mengembangkan sikap-sikap hamba Tuhan yang benar adalah supaya lebih banyak orang mendengar dan menerima Injil Kristus dan beroleh selamat. Satu hal yang perlu dipegang oleh setiap hamba Tuhan dalam situasi apapun yaitu jika ia setia maka ada penghargaan atas kesetiaannya tersebut. Seperti yang tertulis pada ayat 11-13, "Jika kita mati dengan Dia, kitapun akan hidup dengan Dia; jika kita bertekun, kitapun akan ikut memerintah dengan Dia; jika kita menyangkal Dia, Diapun akan menyangkal kita; jika kita tidak setia, Dia tetap setia, karena Dia tidak dapat menyangkal diri-Nya."

\section{KESIMPULAN}

2 Timotius 2: 1-13 menunjukan beberapa sikap hidup yang harus dimiliki oleh hamba Tuhan yang diantaranya kuat dalam kasih karunia, dapat dipercaya, memperhatikan Firman Tuhan, mengikuti teladan Yesus dalam menanggung penderitaan dan sabar dalam menanggung penderitaan. Sikap hidup ini dituliskan Paulus supaya Timotius menjaga kemurnian panggilannya dan tidak terpengaruh ajaran sesat yang ada pada waktu itu. Dengan demikian, penting bagi hamba Tuhan pada masa kini untuk memelihara sikap hidup dalam menjalankan panggilannya dengan setia. Tidak hanya itu, setiap hamba Tuhan perlu mengevaluasi sikap hidup yang dimiliki selama ini, apakah masih benar atau sebaliknya. 


\section{DAFTAR PUSTAKA}

Butarbutar, Ferdinand. "Membangun Pemimpin Hebat Menutur 2 Timotius 2:1-25 Di Gereja Masehi Advent Hari Ketujuh Indonesia." Jurnal Theologia Forum STFT Surya Nusantara 5, no. 1 (2017): 35-49.

Douglas, J D. The New Bible Commentary. London: Intervarsity Press, 1975.

Elwell, Walter A. Baker's Evangelical Dictionary of Biblical Theology. Grand Rapids Michigan: Carlisle, Cumbria, Bakker Pub, 1996.

Green, Jay P. The Interlinear Biblie:Hebrew-Greek-English. Indiana: Sovereign Grace Publisher, 1986.

Gutrhie, Donald. Tafsiran Alkitab Masa Kini Vol. 3. Jakarta: Yayasan Bina Kasih/OMF, 1995. Henry's Matthew. Matthew Henry Commentary On Whole Bible. Peabody: Hendrickson Publisher, 2002.

Jhonston, Philip. IVP Introduction to the Bible. Bandung: Yayasan Kalam Hidup, 2011. Johanes, Erwin. "16 Tahun Cabuli Jemaat, Pendeta Diringkus Saat Hendak Ke Luar Negeri." Harian Aceh.Co.Id. Last modified 2020. Accessed March 7, 2020. http://www.harianaceh.co.id/2020/03/07/mau-kabur-ke-luar-negeri-pendeta-hannylayantara-yang-cabuli-jemaat-ditangkap/.

Jr, Cleon L Rogers, and Cleon L Rogers III. The New Linguistic and Exegetical Key To The Greek New Testament. Grand Rapids Michigan: Zondervan Publishing, 1998.

Kittel, Gerhard, Gerhard Friedrich, and Geoffrey W Bromiley. Theological Dictionary of the New Testament: Abridged In One Volume. Grand Rapids Michigan: Williams B. Eerdmans Publshing Company, 1985.

Mau, Marthen. "Panggilan Timotius Menurut 2 Timotius 2:2 Dan Implikasinya Bagi Kompetensi Guru Pendidikan Agama Kristen." CARAKA: Jurnal Teologi Biblika dan Praktika 1, no. 2 (2020): 180-198.

Murray, Andrew. Like Christ. Pennsylvania: Whitaker House, 1983.

Rukku, Maria, and Daniel Ronda. "Pemimpin Yang Memiliki Integritas Menurut 2 Timotius Pasal 2." Jurnal Jaffray 9, no. 1 (2011): 25-59.

Sapan, Sara L, and Dicky Dominggus. "Tanggung Jawab Penggembalaan Berdasarkan Perspektif 1 Petrus 5:1-4.” Jurnal Teologi Amreta 3, no. 2 (2020): 124-145.

Strong, James. The New Strong's Exhaustive Concordance of The Bible. Nashvile: Thomas Nelson, 1990.

Sudibyo, Tenny, and Areyne Christi. "Implementasi Prinsip Kepemimpinan Rasul Paulus Berdasarkan Surat 1 Timotius 3:1-13 \& 2 Timotius 2:2-6 Di Kalangan Civitas Akademika Sekolah Tinggi Teologi." Jurnal Excelsior Pendidikan 1, no. 1 (2020): 2344.

Swindoll, Charles R. Improving Your Serve: The Art of Unselfish Living. Texas: The World Inc, 1981.

Tenney, Merrill C. Survey Perjanjian Baru. Malang: Gandum Mas, 2001.

Walvoord, John F, and Roy B. Zuck. The Bible Knowledge Commentary: An Exposition Of The Scriptures New Testament. Illinois: Victor Books, 1983.

Wenham, J W. Bahasa Yunani Koine. Malang: SAAT, 1987. 